\title{
THE ROLE OF CAPITAL STRUCTURE IN THE U.S. ENTERPRISES - THE CASE OF CALIFORNIAN SMALL BUSINESSES
}

\section{ROBERT RUMIŃSKI}

University of Szczecin, Faculty of Management and Economics of Services, POLAND

e-mail: mail@robertruminski.com

RECEIVED
ACCEPTED
JEL
CLASSIFICATION

KEYWORDS

ABSTRACT

\author{
18 January 2018 \\ 2 September 2018 \\ G32, L53, 016 \\ capital structure, entrepreneurial finance, small business
}

Small businesses face acute problems in accessing external funds. There is a large interest in finding the optimal capital structure and understanding the access of firms to finance, particularly in the process of financing small enterprises. Small firms tend to be bank dependent for external funds and the adequate capital structure is of crucial importance. This paper is concerned with the role of capital structure in the U.S. small enterprises. The data and statistical analysis derived from the empirical research and empirical study that was done in California are discussed. The paper presents the literature review on the capital structure and its theories. Moreover, it identifies the most important factors influencing the optimal capital structure. Last but not least is a short presentation and analysis of the association between particular empirical research questions regarding the capital structure and selected external factors.

\section{Introduction}

One of the major problems for a small enterprise is to secure the initial capital necessary for the access of potential entrepreneurs to initial credit so as to start their operations. Because of their small size and the lack of substantial public information about their quality, small businesses face acute problems in accessing external funds. There is a large interest in understanding the access of firms to finance, particularly in the process of financing 
small enterprises and startups. Their small turnover usually does not allow to self-finance their business activity by reinvesting profits. Therefore, small companies are forced to use alternative instruments provided by financial intermediaries.

Commercial banks are one of the most important and dominant small business financial capital providers, and a long-term and stable relationship between enterprises and these financial intermediaries is fundamental. Small firms tend to be bank dependent for external funds. On the other hand, banks are cautious about lending money to small businesses, especially start-ups. The banking system for the financing of small enterprises has often been characterized by a short-term approach to secure lending and minimize risk. Some of the reasons are that the staffs of banks have low skills in evaluating and monitoring small business loans, and that banks are afraid of the risks associated with small businesses, especially when borrowing without any tangible collateral.

Moreover, many small enterprises have weak financial structure, do not have a credit history and experience in dealing with banks, and, in many cases being relatively young firms, lack an extensive history from which future performance can be extrapolated. Thus, the adequate capital structure of small (and especially young) enterprises is of crucial importance. Last but not least is the fact that many banks simply do not understand how small business operates.

\section{Literature review}

The theories of capital structure have been changing over the years - starting with the theory of a perfectly competitive market to the most modern ones - specifying the hierarchy of the sources of financing or information asymmetry. There has been no coherent theory and the share of external capital depends on the relation between the enterprise profitability and the market interest rate. If the market interest rate is lower than the enterprise profitability, then it is advisable to take advantage of using external capital, and make use of a financial leverage. Unprofitable and riskier firms consistently use greater leverage. Smaller enterprises have a lower probability of survival (greater risk of failure). It is usually reflected in less favorable terms of debt financing, including higher interest rates to compensate for the higher costs of information collection. Financial intermediaries assess small enterprises as being inherently more risky. Experienced bankers or other specialized financial intermediaries can assess the risks associated with new ventures (startups) better than inexperienced insiders like young, inexperienced entrepreneurs and managers. Lending to small business is more likely to be based on collateral. Therefore, lending may not be based on the expected return, but on the access to collateral. On the other hand, collateral reduces "moral hazard" and "adverse selection." Small businesses lacking an access to high quality collateral suffer from credit rationing (Small businesses..., 1997, p. 18). The abovementioned small business financial weaknesses heavily influence their capital structure. In case a debt financing is not available, the fundamental question arises: is an enterprise owner willing to share power and dilute his/her ownership in exchange for equity capital raised from external investors? (Rumiński, 2005, pp. 8-9).

The capital structure decision constitutes one of the most fundamental issues in corporate finance. As mentioned above, it considers the choice between debt and equity, which is an essential issue of every enterprise's financial policy. Defined as gearing or leverage, it can generally be described as the share proportion (relative amount of capital) between the two main categories of financing sources - equity capital and debt - used in financing the enterprises' activity. It is crucial to select such a capital structure that minimizes the costs of capital and maximizes the value of an enterprise. A majority of researchers recognize that it is a relation of long-term debt to equity, without 
accounting for short-term debt. Such a view is presented by, inter alia, Duliniec (2007) and Jerzemowska (1999). According to them, a capital structure is a part of financing structure, encompassing the structure of liabilities. Its development needs to aim at maximizing enterprise value (Bielawska, 2009, p. 80).

A number of rules and principles are formulated in literature, aiming to facilitate the fulfillment of the main objectives of an enterprise, inter alia, maximizing its market value at a given risk level. Jajuga and Słoński (1998, p. 208) define an enterprise capital structure narrowly, stating that it is a combination of a given company's equity and external capital. It excludes the possibility of the optimization of the total capital financing of an enterprise. The final capital structure is a result of the impact of a large number of various factors. Their variability, variety, and mutual ties make the actions aimed at determining an optimal capital structure to be searching for and getting closer to target values, rather than indicating one optimal value (Golej, Prędkiewicz, 2015, p. 181). The objectives of shaping a capital structure must comply with the enterprise management objectives.

The issue of an optimal mixture of financing is still contentious despite voluminous empirical evidence. Within the couple of decades, numerous studies have been conducted to test major competing theories. The theories of capital structure started to emerge in the 1950s. The development of those theories started with Durand's work in 1952, who, in his search for an optimal ratio of external capital to equity, introduced the concept of cost of capital. According to him, the cost of external capital was an interest on a contracted debt, whereas the cost of equity - the cost of an alternative equal to the rate, free of any risk increased by a risk premium (Gajdka, 2002, pp. 66-67).

A different perspective is presented by Modigliani and Miller (1958, pp. 261-297; 1962; 1963, pp. 433-443), whose theory refers to the relation between the company's debt and its own capital (equity) (Skowronek-Mielczarek, 2003, p. 37). The substitution theory focuses on the interchangeably applied equity and debt. Establishing their mutual proportions should bring about the optimum structure shape of the sources engaged. The pecking order and the trade-off theories provide two different points of view. They are formulated as specific models, and in real life situations they are easy to reject on a variety of dimensions. Both theories, often presented as unifying ones, have been illustrated in specific models with simplifying assumptions. Shyam-Sunders and Myers (1999), Fama and French (2002), and Flannery and Rangan (2006) attempted to distinguish between the pecking order and the tradeoff theories. The researchers found conflicting evidence - some supporting and some refuting each theory. The two theories of capital structure (pecking order and trade-off) together with the market-timing theory emerged as the best explanations for the capital structure decision. These three theories have become the finance profession's best explanations for the capital structure decision. Nonetheless, the first two are relevant for privately held enterprises that do not issue publicly traded securities. Whilst many studies tackle the capital structure decision, most empirical work considers large publicly listed firms (Degryse, Goeij, Kappert, 2012, p. 1).

\section{Method and pesults}

A research survey was used in the study regarding the cooperation of the small business sector with institutions of financial intermediation. The survey was addressed to the management of the small business sector operating in the selected key areas of Los Angeles and a study sample comprised of 550 active enterprises.

The equity capital (e.g., personal, angel, venture, stock) constitutes nearly $47 \%$ of the financial capital in use by the surveyed businesses. The other two categories of the capital in use are the following: debt (e.g., loan, lines, leases) $-27.9 \%$, and retained earnings (earned surplus) $-25.2 \%$ (Figure 1). 


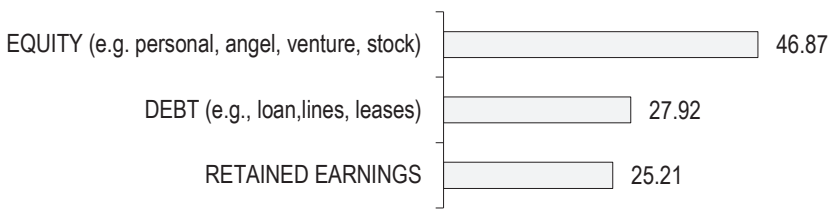

Figure 1. The percentage share of financial capital in use by small business

Source: own elaboration.

Table 1. The percentage share of financial capital in use by small business - statistics

\begin{tabular}{lcccc}
\hline \multicolumn{1}{c}{ Answer } & Min Value & Max Value & Average Value & \multicolumn{2}{c}{ Standard Deviation } \\
\hline EQUITY (e.g. personal, angel, venture, stock) & 0 & 100 & 46.87 & 38.62 \\
DEBT (e.g., loan, lines, leases) & 0 & 88 & 27.92 & 29.24 \\
RETAINED EARNINGS & 0 & 100 & 25.21 & 27.91 \\
\hline
\end{tabular}

Source: own elaboration.

Considering different types of equity, personal stock is prevailing (69.03\%). Angel Investors, friends and family, as well as new shareholders constitute $6.71 \%, 6.42 \%$, and $3.39 \%$, respectively (Figure 2).

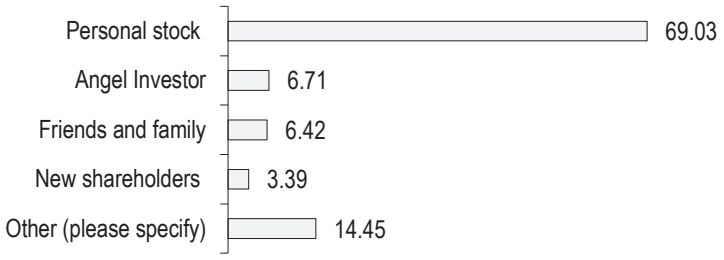

Figure 2. Types of equity in use by small business

Source: own elaboration.

Table 2. Types of equity in use by small business - statistics

\begin{tabular}{lcccc}
\hline \multicolumn{1}{c}{ Answer } & Min Value & Max Value & Average Value & Standard Deviation \\
\hline Personal stock & 0 & 100 & 69.03 & 42.87 \\
Angel Investor & 0 & 100 & 6.71 & 23.20 \\
Friends and family & 0 & 100 & 6.42 & 19.73 \\
New shareholders & 0 & 100 & 3.39 & 16.77 \\
Other (please specify) & 0 & 100 & 14.45 & 34.67 \\
\hline
\end{tabular}

Source: own elaboration.

Between the responses to the question please indicate the percentage share of financial capital in use by your business - EQUITY and the responses to the question within the last FIVE years have you looked for a new 
primary financial institution?, there is a statistically significant moderate positive correlation. Pearson's coefficient is 0.521628. The average level (arithmetic mean) of equity in the surveyed enterprises is $61.5 \%$ (Table 3). Despite the fact that a dependency was observed indicating that the increase in the share of equity capital has an impact on the positive decision to start looking for a new primary financial institution, it is not possible to draw clear conclusions. This relationship can, for example (hypothetically) be associated with a situation in which an investor uses his/her own funds to finance a business venture, and his/her potential for further financial cooperation (raising capital from his/her primary financial institution) has exhausted. Therefore, he/she needs to establish a cooperation with a new financial institution through which it will expand its financial capacity to act. It should also be borne in mind that there are different forms of equity capital, and an example of the situation described above does not determine the success resulting from taking the above action.

Table 3. Pearson's coefficient - the association between questions

\begin{tabular}{lccc}
\cline { 2 - 4 } & $\begin{array}{c}\text { Average (equity) } \\
(\%)\end{array}$ & $\begin{array}{c}\text { Standard } \\
\text { deviation (\%) }\end{array}$ & $\begin{array}{c}\text { Within the last FIVE years have you looked } \\
\text { for a new primary financial institution? }\end{array}$ \\
\hline $\begin{array}{l}\text { Please indicate the percentage share of financial capital } \\
\text { in use by your business (equity) }\end{array}$ & 61.50 & 41.57 & 0.521628 \\
\hline
\end{tabular}

Source: own elaboration.

Between the responses to the question please indicate the percentage share of financial capital in use by your business (retained earnings) and the responses to the question thinking about your business's principal bank, please rate your level of satisfaction with the following aspects of your loan financing (level of commissions and fees), there is a statistically significant moderate positive correlation. Pearson's coefficient is 0.461599 (Table 4). This indicates that increasing the level of retained earnings is followed by an increase in satisfaction with the level of commissions and fees. This association is surprising, and, therefore worth pursuing further in-depth empirical research.

Table 4. Pearson's coefficient - the association between questions

Thinking about your business's principal bank, please rate your level of satisfaction with the following aspects of your loan financing? (level of commissions and fees)

Please indicate the percentage share of financial capital

in use by your business (retained earnings)

0.461599

Source: own elaboration.

Between the responses to the question please indicate the percentage share of financial capital in use by your business (retained earnings) and the responses to the question thinking about your business's principal bank, please rate your level of satisfaction with the following aspects of your loan financing (level of loan interest rates), there is a statistically significant positive moderate correlation. Pearson's coefficient is 0.545972 (Table 5). This indicates that increasing the level of retained earnings is followed by an increase in satisfaction with the level of loan interest rates. This association is surprising as well, and, therefore worth pursuing further in-depth empirical research. However, it is possible to draw a fairly general conclusion that the improvement in the company's financial 
condition using retained earnings can contribute - assuming the effective use of this capital leading to increased profitability - to a better perception of the level of commissions and fees imposed by financial institutions.

Table 5. Pearson's coefficient - the association between questions

Thinking about your business's principal bank, please rate your level of satisfaction with the following aspects of your loan financing? (level of loan interest rates)

Please indicate the percentage share of financial capital in use by your business (retained earnings)
0.545972

Source: own elaboration.

Between the responses to the question please indicate the percentage share of financial capital in use by your business (retained earnings) and the responses to the question thinking about your business's principal bank, please rate your level of satisfaction with the following aspects of your loan financing (the amount of collateral required by bank), there is a statistically significant positive moderate correlation. Pearson's coefficient is 0.546420 (Table 6). This indicates that the increase in retained earnings is followed by the increase in the level of satisfaction with the amount of collateral required by banks. The increase in retained earnings can contribute directly or indirectly to the growth of the company's fixed assets or, more generally, to the improvement of the enterprises' financial standing. In this context, banks will have more opportunity to choose a satisfactory level of security. Therefore the appropriate choice of security (in terms of better quality and thus lower in terms of the level/quantity) can affect the higher level of satisfaction of customers (enterprises) in terms of the amount of collateral required by the bank.

Table 6. Pearson's coefficient - the association between questions

Thinking about your business's principal bank, please rate your level of satisfaction with the following aspects of your loan financing? (the amount of collateral required by bank)

Please indicate the percentage share of financial

capital in use by your business (retained earnings)

0.546420

Source: own elaboration.

Between the responses to the question please indicate the percentage share of financial capital in use by your business (retained earnings) and the responses to the question thinking about your business's principal bank, please rate your level of satisfaction with the following aspects of your loan financing (conditions for loan repayment), there is a statistically significant positive moderate correlation. Pearson's coefficient is 0.477527 (Table 7). This points to the fact that the increase in the proportion of retained earnings is followed by the increase in the level of satisfaction with the conditions for loan repayment. The increased level of retained earnings may (but need not) improve the financial condition (depending on the purpose for which the retained earnings will be used, and the investments made by the company), and, therefore an increase in the level of satisfaction with the conditions for loan repayment resulting from the improved financial standing of the company.

This association is interesting and worth pursuing in an extended empirical research on the issue of the motives of the behavior of respondents, i.e., the effect of increasing retained earnings at the perception (assessment) of the loan financial parameters (cost drivers). 
Table 7. Pearson's coefficient - the association between questions

\begin{tabular}{lc}
\cline { 2 - 2 } & $\begin{array}{c}\text { Thinking about your business's principal bank, please rate your level of satisfaction } \\
\text { with the following aspects of your loan financing? (conditions for loan repayment) }\end{array}$ \\
\hline $\begin{array}{l}\text { Please indicate the percentage share of financial capital } \\
\text { in use by your business (retained earnings) }\end{array}$ & 0.477527 \\
\hline
\end{tabular}

Source: own elaboration.

Between the responses to the question please indicate the percentage share of financial capital in use by your business (equity) and the responses to the question thinking about your business's principal bank, please rate your level of satisfaction with the following aspects of your loan financing (the amount of collateral required by bank), there is a statistically significant negative moderate correlation. Pearson's coefficient is -0.463889 (Table 8). This indicates that the increase in the proportion of equity capital (e.g., personal, angel, venture, stock) causes the decrease of the level of entrepreneur's satisfaction with the amount of collateral required by the bank. It is difficult on this basis to draw firm conclusions without conducting further extended empirical study. The reason for such a relationship can be a perception of bank collateral by investors (business owners, angel investors, venture capitalists, or stock holders) as a means of reducing the flexibility of a company and preventing, e.g., full and unrestricted disposal of company assets.

Table 8. Pearson's coefficient - the association between questions

\begin{tabular}{lcc}
\cline { 2 - 2 } & $\begin{array}{c}\text { Thinking about your business's principal bank, please rate your level of satisfaction } \\
\text { with the following aspects of your loan financing? (the amount of collateral required by bank) }\end{array}$ \\
\hline $\begin{array}{l}\text { Please indicate the percentage share of financial } \\
\text { capital in use by your business (equity) }\end{array}$ & -0.463889 \\
\hline
\end{tabular}

Source: own elaboration.

\section{Conclusions}

The determinants of companies' capital structure are the focus of interest of numerous researchers verifying the possibility of applying the theory of finance in practice, taking into consideration the impact of the legal and economic system, macroeconomic situation, and other factors, such as a life cycle stage, debt maturity date, or reporting quality. Finding the optimized financial structure of enterprise is not an easy goal. Managing capital structure allows for minimizing the cost of capital, and accessing low cost capital maximizes venture's value. Therefore, raising adequate capital is a key to growth. Microenterprises, especially startups, face the biggest financial obstacles. Currently, almost every enterprise is characterized by an inadequate proportion of equity capital. New ventures have large working capital, and debt financing comes with maturity and stable cash flows. Investments are usually burdened with high risk, which decreases the possibilities of obtaining external capital. Banks finance projects with a limited risk exposure and those which hold promise of fairly certain profits. If they do undertake the financing of uncertain projects, then it is inseparably bound with an increased credit cost and less favorable terms of financing, which in turn lower the effectiveness of the venture. The degree of indebtedness influences the enterprises' creditworthiness. 
Small business is characterized by the lack of required credit collateral. Therefore, it is essential to have a sufficient amount of equity. This type of capital may constitute a substitute for the lacking credit security required by banks. An increase in small enterprise equity results in an increase of its creditworthiness and to some extend its trustworthiness. The increase in the share of equity capital has an impact on the positive decision to start looking for a new primary financial institution. The improvement in the company's financial condition using retained earnings can contribute - assuming the effective use of this capital leading to increased profitability - to a better perception of the level of commissions and fees imposed by financial institutions. The increase in retained earnings is followed by the increase in the level of satisfaction with the amount of collateral required by banks. The increase in retained earnings can contribute directly or indirectly to the growth of the company's fixed assets or, more generally, to the improvement of the enterprises' financial standing. The increased level of retained earnings may (but need not) improve the financial condition (depending on the purpose for which the retained earnings will be used, and the investments made by the company), and, therefore an increase in the level of satisfaction with the conditions for loan repayment resulting from the improved financial standing of the company. The increase in the proportion of equity capital (e.g., personal, angel, venture, stock) causes the decrease of the level of entrepreneur's satisfaction with the amount of collateral required by the bank.

\section{References}

Bielawska, A. (2009). Nowoczesne zarządzanie finansami przedsiębiorstwa. Warszawa: C.H. Beck.

Degryse, H., Goeij, P., Kappert, P. (2012). The impact of firm and industry characteristics on small firms' capital structure. Small Business Economics. Springer.

Duliniec, A. (2007). Finansowanie przedsiębiorstwa. Warszawa: PWE.

Durand, D. (1952). Costs of Debt and Equity Funds for Business: Trends and Problems of Measurement. Conference on Research in Business Finance. National Bureau of Economic Research.

Fama, E.F., French, K.R. (2002). Testing Trade-Off and Pecking Order Predictions About Dividends and Debt. The Review of Financial Studies, $15(1), 1-33$.

Flannery, M.J., Rangan, K.P. (2006). Partial Adjustment Toward Target Capital Structures. Journal of Financial Economics, 79 (3), 469-506.

Gajdka, J. (2002). Teorie struktury kapitału i ich aplikacja w warunkach polskich. Łódź: Wydawnictwo Uniwersytetu Łódzkiego.

Golej, R., Prędkiewicz, K. (2015). Zarządzanie finansami przedsiębiorstwa. Wrocław: Wydawnictwo Marina.

Jajuga, T., Słoński, T. (1998). Finanse spółek. Długoterminowe decyzje inwestycyjne i finansowe. Wrocław: Wydawnictwo Akademii Ekonomicznej.

Jerzemowska, M. (1999). Kształtowanie struktury kapitału w spółkach akcyjnych. Warszawa: Wydawnictwo Naukowe PWN.

Rumiński, R. (2005). The analysis of the Polish financial capital market contribution to small and medium enterprises. Frankfurt, Germany: Master of Business Administration, Europa Universitat Viadrina.

Skowronek-Mielczarek, A. (2003). Wybory źrodeł finansowania w małych i średnich przedsiębiorstwach. In: E. Orechwa-Maliszewska, A. Kopczuk (eds.), Finansowe aspekty funkcjonowania małych i średnich przedsiębiorstw. Białystok: Wydawnictwo Wyższej Szkoły Finansów i Zarządzania w Białymstoku.

Small businesses, job creation and growth: Facts, obstacles and best practices (1997). OECD. Retrieved from: https://www.oecd.org/ cfe/smes/2090740.pdf.

Cite this article aS: Rumiński, R. (2018). The role of capital structure in the U.S. enterprises - the case of Californian small businesses. European Journal of Service Management, 3 (27/2), 371-378. DOI: 10.18276/ejsm.2018.27/2-45. 